\title{
䣿 $\mathrm{K} \alpha \gamma \mathrm{Q}^{1}$ \\ Kaygı Uludağ Üniversitesi Fen-Edebiyat Fakültesi Felsefe Dergisi \\ Uludağ University Faculty of Arts and Sciences Journal of Philosophy \\ Sayı 23 / Issue 23 | Güz 2014 / Fall 2014 \\ ISSN: 1303-4251
}

\section{Research Article}

Araştırma Makalesi

\section{Metin BECERMEN}

Assoc. Prof. Dr. | Doç. Dr.

Uludag University, Faculty of Arts and Sciences, Department of Philosophy, Bursa-Turkey

mbecermen@uludag.edu.tr

\section{A Reading Essay on Hegel's View of Right}

\begin{abstract}
In this study, Hegel's view of right shall be comprehensively taken in hand which Hegel had mentioned in his Philosophy of Right and the concept of the constitutional state idea shall be emphasized in reference to the present problems pursuant to Hegel's judgments. In this regard, to what extent the forming of a state which is subject to the constitution can provide opportunities for us to cope with the existing problems shall be tried to put forward.

Primarily, the concept of universal put forth by Hegel shall be addressed and the importance of thinking upon the possibility of a universal right shall be emphasized. Later on, Hegel's approach towards right shall be explained, thus creating the framework of the concept of right. Lastly, an evaluation shall be carried out depending on Hegel's ideas and what meanings of Hegel's statements which may hold in today's world shall be tried to set forth.
\end{abstract}

\section{Keywords}

Freedom, Laws, Right, the Constitution, Universal. 
Philosophy deals with ideas not with the mere concepts.

Hegel

\section{On Hegel's Concept of Universal}

Hegel, who stated that each part of the philosophy is a whole, a circle enclosing within itself, suggested that philosophical idea is there, inside a particular certainty or element. Within this context, a particular circle establishes a larger area by disintegrating the limits of its own element since it contains a unity within itself. The whole presents itself as a circle among the circles each of which are compulsory moment thus the arrangement of its unique elements forms the idea; the idea appears in all singular circles in a way that is equal to its own share regarding them (Hegel, 2004: 66).

On the other hand, according to Hegel, something that is audible is a singular and consumable thing; the permanent aspect of it can be known only by thinking about it. According to Hegel, who stated that the nature showed us an endless multitude of shapes and phenomena, we feel a need to bring a unity to this chaos; for this reason, we make comparisons and try to know about the universe of each of these. Here, it can be seen how "thinking about something" seeks for the permanent thing, which is invariable with time and certain within itself and which manages the particular. While determining the universal this way, we see that it provides the antithesis for something different and because of this other thing it is a mere, direct, external and singular thing against the indirect, internal and universal thing. According to Hegel, who stated that this universal cannot exist as a universal in external world, the type cannot be perceived as the type. For this reason, dynamics' law of the celestial bodies is not written in the sky. So, the universal cannot be heard or seen; on the contrary, it only has a capacity of being understood (Hegel, 2004: 81).

Hegel names the driving principle of the concept "dialectic" in terms of both the analysis of the qualities and the formation of the universal (Hegel, 1991a: 56; 1986: 84). On one hand, determinations of the concept within its own developmental process are concepts themselves while, on the other hand, these take the form of existence since the concept is an idea in terms of content. Therefore, the sequence of concepts that emerges is a concrete sequence of figures and the science of philosophy should examine these that way (Hegel 1986: 85; 1991a: 57).

The purpose of philosophical investigation for Hegel is to draw away the incidental which is the same thing with external necessity. A general purpose should be sought on the mental grounds in the history. Something that is mental is a thing that exists for its own. The world is the appearance of this singular mind. Philosophy will not skew the right thing since it is reasonable. Therefore, philosophy only works when it takes the idea as a reference. 


\section{II- Hegel's View of Right}

After these explanations regarding the concepts, we can consider what Hegel said about right. According to Hegel, the subject of scientific right philosophy is the idea of right, that is to say, the concept of right and realization of this concept (Hegel, 1986: 29; 1991a: 33). Right generally has a positive quality because: A) it has a formal character valid for a certain state and this legal validity forms the guiding principle of its knowledge, that is to say, the science of positive right; B) in terms of content, law has a positive element and this element results from: a) special national character and historical development level of each nation and the general whole of the conditions affiliated with natural obligations; b) the obligation for applying an universal concept to a special quality of subjects and areas, which was given externally for a positive right system (this applications is an application formed of subjecting the special to the universal and including the capacity to understand to the concept other than speculative thinking and concept); c) the right provisions needed to make the final decisions in reality. According to Hegel, natural or philosophical right and the positive right are different things but turning this difference into a contradiction or a conflict will be an important mistake (Hegel, 1991a: 35). On the other hand, the rights gain a determined existence with being declared as positive right. For this reason, the knowledge of something that is a right in the positive right, that is to say, something that is legit, finds its resource in the legal things. In this sense, the science of positive right is a historical science based on the principle of authority (Hegel, 19896: 212-3; 1991a: 176).

On the other hand, the thing that is concrete and real (everything that is real is concrete) is only universal and it finds its counterpart in a thing that is special and certain. However, this special thing is something that reconciles with the universal and becomes equal with it by turning to itself. This unity is individuality (Hegel, 1986: 55; 1991a: 43).

Hegel focuses on the concept of will while he explains the subject of universality. Will is the unity of finite and infinite. This is a quality that turned to itself; thus ascending to universality, that is to say, this is individuality. Self-determination of ego means both ego presenting itself as the denial of itself, that is to say, in a limited and determined manner and it remaining the same in spite of that, that is to say, remaining within its similarity with itself and universality and being dependent on nothing but itself in the end (Hegel, 1986: 55; 1991a: 43).

In addition to that, by making some decisions will presents itself as a desire that is different from a certain person's desire and differs itself from that person. However, in this case direct will is formal since it is finite and its shape and content is different. Only abstract decisions belong to it and the content of this decision is not the content and product of its freedom yet (Hegel, 1986: 64; 1991a: 46). But the unique determination, which was not determined in terms of self, is only the reality of the formal universality in the above-mentioned material; it is a universality, will and freedom that is self determinant. When will consider its own content, object and purpose and considers the universal as infinite form, it will ceases being only free will within self and becomes free will for self; it is now the idea within its reality. Free will is now an idea that exists here (Hegel, 1986: 71-2; 1991a: 50). Will is universal because 
all kinds of threats and individual qualities were eliminated in it (Hegel, 1986: 75; 1991a: 52).

According to Hegel, the right and the free will opinion that provides a starting point for the science of right is beyond the wrong point of view which accepts that men can be slaves because they are just a natural creature and only a concept (Hegel, 1986: 123-4; 1991a: 72).

Within this context, the ultimate goal of a free spirit or - so to speak - the ultimate instinct is to turn its freedom into its own object, that is to say, objectify its freedom thus turning what is inside the self of wanting something that is "for itself" as an idea. Shortly, the abstract concept of will remains as "free will that demand free will" with a general expression (Hegel, 1986:79; 1991a: 54). Freedom, on the other hand, is only the effect of the spirit on its opinion of itself and its distinguishing itself from the nature (Hegel, 1986: 350; 1991a: 166).

According to Westphal, Hegel mentions in Philosophy of Right that there are two basic realities in reaching freedom. These are reaching your purpose and acting intentionally. Therefore, according to Hegel, acting freely requires both reaching your purposes and to harmonize the results of the act and the intention for doing it. According to Hegel, conditions for free act to succeed are extremely complex and it requires being a member of a well-regulated state at the end (Westphal, 1996: 303). Within this context, existence of freedom in general, that is to say free will, is the right. In this case, the right, by definition, is freedom as an idea (Hegel, 1986: 80; 1991a: 54).

In addition to that, both subjective and objective morality are special rights; because, each of these is a determination and realization of freedom. According to Hegel, each right contains the concept of freedom, the highest determination of the spirit and nothing can have a substantive existence against this. However, the conflict has a different side; it is limited so it is something that is subject to another element. According to him, only the right of universal spirit is ultimate and infinite (Hegel, 1986: 83-4; 1991a: 55-6).

On the other hand, free will by itself and free will according to the developmental stages of the idea of free will for self is firstly direct; in this case, the concept is abstract. It is something that is direct without any empirical existence. This is the area of abstract and formal right.

In addition to that, free will is turning to itself from external existence. For this reason, it has a subjective and individual character contrary to the universal. This is the area of subjective morality.

Finally, unity and reality of these two abstracts will be discussed. At this point, it was not enough to be perceived in thought and there is an idea of goodness that emerged in will for itself and the external world. Freedom exists as a substance now; this is the idea in its self and within its universal existence for itself, that is to say, this is morality.

On the other hand, moral substance is also natural spirit, that is to say, the family; divided and phenomenal spirit, that is to say, civil society, is the state as freedom. This freedom is universal and objective within freedom autonomy of the 
state's special will. At this point, the organic and real spirit in question is firstly the spirit of a certain nation. Later, it displays and actually realizes itself in relations between different special and national spirits. This goes on until its universal spiritual manifestation within universal history; the right of universal spirit is the highest level of right (Hegel, 1986: 85-7; 1991a: 57-8).

At this point, Hegel gives explanations regarding various institutions and operation of these institutions. Within this context, he determinates regarding family, civil society and state. In addition to other things, family provides an institutional concept to conventionalize and rationalize the sexual desire and a way to perform the task of raising the next generation. (Westphal 1996: 310) Civil society contains institutions and practices regarding production, distribution and consumption of the products covering various needs and desires. Westphal states that Hegel defined this as “system of needs" (Westphal 1996: 311).

On the other hand, civil society includes three types of institutions. These are judicial management, public authority and corporations. Judicial management reviews, changes, interprets and manages the legal rights. Public authority is responsible for removing the barriers in front of reaching individual aims or correcting the situation (Westphal, 1996: 311). Final institution in the Hegel's state is the central government (Westphal, 1996: 312).

State is actual reality of concrete freedom (Hegel, 1986: 406; 1991a: 203). The state is both an institutional structure established for family and civil society which limits personal rights and interest and the reason why all of these exist.

According to Hegel, before anything else, main political structure means organization of the state and the process of its organic life within its relation to itself. It differentiates various moments during the process and devolves them as constant existences. State also is a single and special individual; as an individual like itself, it established relations with other individual like himself. That is to say, it turns its differentiated organism to outside and - within this determination - makes its different existences gain ideality within itself (Hegel, 1986: 374; 1991a: 220). The actual character of the state as a political existence is substantial unity, that is to say, "ideality of moments" (Hegel, 1986: 441; 1991a: 226).

On the other hand, as a political agent, the state separates into substantial differences, such as legislative power determining and establishing the universal; executive power including special areas and individual states; ruling power as the subjective power for the final decision demand will. Separate powers gather as a universal unity in the personality of the ruler and the ruler becomes the basis and the top of the whole formed by the thing called constitutional monarchy (Hegel, 1986: 435; 1991a: 222).

Hegel attributes ruling not only to rulers but to the state as a whole. Even if each element of the state has a role defined institutionally, ruling does not belong to any of these elements; also, no duty of the state belongs to a person (Hegel, 1986: 442-3; 1991a: 226-7). 
At this point, Hegel mentions the progress of universal spirit throughout the history. Within the progress of universal spirit, the states, nations and individuals appear at the historical scene with their well-determined special principles. Special principles of each of them find their expression within its main political structure and gains reality throughout the development of its historical situation. Their conscious is limited with this principle and they consider the interest of this as their own interest; but they are also unconscious tools and moments of a secret activity, the universal spirit working within themselves. While special forms are eliminated and get lost within its deep activity, the spirit prepares the way to pass to the next higher stage for its own within itself (Hegel, 1986: 505; 1991a: 267).

On the other hand, the essence of spirit is freedom. The purpose of spirit throughout the history is the freedom of the subject. According to Hegel, the thing that has continuity is the purpose, the state and each states is the purpose for itself. The state is the reality with which an individual has freedom and enjoys it. Freedom is objectified and realized positively with the state, arbitrary behaviors of a single person are not freedom according to Hegel. Therefore, a person meets his mental existence only with the state. On the other hand, will itself is an activity and this activity finds its counterpart in the external world as subjective will. Principle of will is to exist for your own: this requires externalization and finiteness. Therefore, the state is a subject in the world history which was determined more closely, freedom gains subjectivity with it and a person lives by enjoying this subjectivity. Because the right is the objectivity of the spirit and it is an approved form of the will. Only the will abiding by the laws is free. Therefore, the mental thing is compulsory with its spirituality and we are free to the extent that we know it as the right and the spirit of our substance. According to Hegel, subjective and objective will reconciles and unites in the same enlightened whole in this case. Hegel states that concept of an object is the same thing with is nature. The thing that makes the state a state is the laws. The individual abides by these rules and he knows that he is free thanks to this abiding: therefore, he meets his own will. So, the knowledge and will unites at this point (Hegel 1991b:126).

In addition to that, the state will seem like an abstraction when considered on its own. This abstraction gains life and reality firstly with the constitution. A distinction of managing people and the managed is made by means of the constitution. Therefore, the first distinction of the state will be the distinction of managing people and the managed people. The thing brought by the constitution is turning the state into a reasonable and political existence and revealing the elements in the concept freely. Therefore, the powers will be separated and be completed one by one, contribute to a purpose freely and provide an organic whole by uniting in this purpose. As a result of this, the state will be the same with mental freedom which considers itself subjective and which exists for itself. Because, the subjectivity of this freedom is about its elements remaining not as mere thought but being realized in practice.

Hegel considers government under the general topic of constitution. He not only stated that the constitution should be considered permanent but it was subject to change and it would get mature by the time (Hegel, 1986: 465; 1991a: 241). What Hegel said about the laws, that is to say, the thought suggesting laws should be certain to be applied, is also valid for the constitution. For this reason, it is necessary for the 
constitution and other laws to have a quality of being valid in a certain place and situation and this changes during the implementation process of the law. Although this situation can be considered as in contradiction with the nature of right, this is not the case; because Hegel states that the laws find their justifications within the functions they fulfilled in an integrated society. As the conditions change, the laws should change in order to remain legit and effective. Therefore, countries can change their constitutions slowly and turn them into something way different from the constitution at the beginning. It can be said that Hegel considered this not as an inevitable compromise made for historical contingency but as a mental process including the collective and gradual review of legal conditions necessary in order to obtain and maintain the freedom (Westphal, 1996: 312-3).

\section{Conclusion}

Hegel suggests that each state should be structure on a constitutional basis, that is to say, make arrangements within the framework of a constitution. It is necessary to do that by taking into consideration an individual's ability to use his freedom as a free citizen. As a final objective, it can be discussed to establish a world constitution taking basis the citizenship of world. But it is necessary to provide this by making new arrangements during every age and in any condition - both in constitutional and legal terms.

For this reason, we can mention the possibility of a universal right. The constitution should be established by taking into consideration the demand/wishes of each citizen and it should pave the way for them to be free citizens as a person. According to this, the laws should be regulated based on the constitution. Thus, it will be possible to raise free individuals and the road to individual freedom will be paved. 


\section{Hegel'in Hukuk Görüşü Üzerine Bir Okuma Denemesi}

\section{Özet}

Bu çalışmada, Hegel'in Hukuk Felsefesinin Ilkeleri kitabında dile getirdiği hukuk görüşü ayrıntılı bir şekilde ele alınacak ve onun düşünceleri çerçevesinde günümüz sorunları karşısında anayasal devlet düşüncesinin ne ifade ettiği üzerinde durulacaktır. Bu bağlamda anayasaya bağlı bir devlet örgütlenmesinin varolan sorunların üstesinden gelmede bize nasıl bir imkan sunacağı gösterilmeye çalışılacaktır.

Öncelikle, Hegel'in evrensel kavramı üzerinde durulacak ve evrensel bir hukukun imkanı üzerine düşünmenin önemi vurgulanacaktır. Daha sonra, onun hukuk fikrini ele alışı açıklanacak ve bu şekilde hukuk kavramının çerçevesi oluşturulacaktır. Son olarak da onun düşüncelerine bağlı olarak bir değerlendirme yapılacak ve Hegel'in söylediklerinin ne bugün ifade ettiği ortaya konmaya çalışılacaktır.

Hegel, her bir devletin anayasal bir temel üzerinde yapılanması, yani bir anayasa çerçevesinde bir düzenleme yapmasına vurgu yapmaktadır. Bunu da, bireyin özgürlüğünü, özgür bir vatandaş olarak eyleyebilmesini hesaba katarak yapmak gerekmektedir. Nihai hedef olarak da dünya yurttaşlığını esas alacak bir dünya anayasası oluşturulması söz konusu olabilir. Ama her çağda ve her koşulda -gerek anayasal gerekse yasal- yeni düzenlemeler yaparak bunun sağlanması gerekmektedir.

Hegel'in yasalar için söylediği şey, yani yasaların uygulanabilmesi için belirli olması gerektiği düşüncesi Anayasa için de geçerlidir. Bu nedenle, Anayasa ve diğer yasaların belirli yer ve durumda geçerli olan bir özelliğe sahip olmaları gerekir, bu ise yasanın uygulanma süreci içinde değişime uğrar. Aslında bu durum hukukun doğasına aykırı gibi görülebilecek olsa da öyle değildir; çünkü Hegel yasaların gerekçelerini bütünleşmiş bir toplum içinde o anda yerine getirdikleri işlevde bulduklarını vurgulamaktadır. Koşullar değiştikçe, meşru ve etkili kalmak için yasaların da değişmesi gerekmektedir. Bu şekilde, ülkeler Anayasalarını yavaş yavaş değiştirerek ilk baştakinden çok farklı bir duruma getirebilirler. Hegel'in bunu tarihsel olumsallığa verilen kaçınılmaz bir ödün olarak değil, özgürlük elde etmek ve bu özgürlüğü korumak için gerekli hukuki koşulların kolektif bir şekilde tedricen gözden geçirilmesini içeren akılsal bir süreç olarak gördüğü söylenebilir.

$\mathrm{Bu}$ nedenle, evrensel bir hukukun olabilirliğinden söz edebiliriz. Anayasa her bir yurttaşın istemlerini/taleplerini hesaba katarak oluşturulmalı ve bir kişi olarak özgür vatandaşlar olabilmelerinin önünü açmalıdır. Buna göre, yasaların da anayasaya bağlı olarak düzenlenmesi gerekmektedir. Bu şekilde, özgür bireylerin yetişmesi sağlanabilecek ve bireysel özgürleşmenin önü açılabilecektir.

\section{Anahtar Sözcükler}

Anayasa, Evrensel, Hukuk, Özgürlük, Yasalar. 


\section{REFERENCES}

HEGEL, G. W. (1986) Grundlinien der Philosophie des Rechts, Suhrkamp Verlag Frankfurt am Main.

HEGEL, G. W. (1991a) Hukuk Felsefesinin Disiplinleri, trans. Cenap Karakaya, İstanbul: Sosyal Yayınlar.

HEGEL, G. W. (1991b) Tarihte Akll, trans. Önay Sözer, İstanbul: Ara Yayınc1lk.

HEGEL, G. W. (2004) Felsefi Bilimler Ansiklopedisi I Mantık Bilimi, trans. Aziz Yardımlı, İstanbul: İdea Yayınları.

WESTPHAL, K. (1996) "Hegel'in Hukuk Felsefesinin Temel Bağlam ve Yapısı", trans. Doğan Şahiner, Cogito, Sayı 9, İstanbul: YKY, pp. 294-316. 